\title{
EDITORIAL: SOCIAL AND ENVIRONMENTAL ACCOUNTING RESEARCH (SEA) - A SPECIAL ISSUE?
}

\section{SEA - A SPECIAL ISSUE?}

For what is now an extended period of time, a number of researchers have been working in what could be described as "an isolated, very small and persecuted community... seeking to reify this mysterious oddity that was social accounting (emphasis in original)" (Gray, 2007, p. 2). However, with increasing commercial and regulatory emphasis globally on environmental degradation and rehabilitation, climate change and the social responsibilities of the corporate world, this isolated, small community has not only gained a voice, but an increased profile and credibility for researchers in the area. As such, social and environmental accounting (SEA) research (as it is now known) boasts both a history and a future as a stand-alone sub-discipline of accounting research. More and more emerging scholars are opting for research programs that encompass or engage with SEA issues. Indeed, many major accounting conferences (such as the European Accounting Association (EAA) and Accounting and Finance Association of Australian and New Zealand (AFAANZ)) offer dedicated SEA streams.

SEA is no longer a special issue! But as noted above, this was not always the case.....

\section{BACKGROUND TO CSEAR}

Social and environmental accounting have been of interest and concern to Australian academics since the 1970s, most prominently evidenced through the publication of the Social Accounting Monitor by Mathews and Guthrie. On the basis of the continuous and growing worldwide attention, the Centre of Social and Environmental Accounting Research (CSEAR) was founded in 1991 as a platform for academics and practitioners interested and dealing with issues relating to SEA. An annual summit was initiated to provide opportunity for exchange and networking, with an emphasis on the latter. Since then, membership has grown internationally and CSEAR conferences have been held and are planned for around the world. It is in the tradition of these summits (or Summer schools) to welcome and nurture emerging scholars in the field as well as increasing the profile of SEA research in accounting research by providing a forum which is academically rigorous yet supportive.

CSEAR has recently undergone (and is still doing so) some significant changes in an effort to position the organisation for future challenges and to increase the profile and professional image of practitioners and researchers in the field (see e.g. Gray $2006 \mathrm{a}, \mathrm{b}$ ). Borrowing from Milne and Ball's (2007) conference plenary terminology ${ }^{1}$, with the grandfathers in the field beginning to reduce their workloads (or, dare we say, starting their retirements?), the established and privileged researchers are starting to take a leading role in the governance of CSEAR and future direction of SEA research more generally. This transition could potentially provide even greater opportunities for emerging scholars in the field, referred to by Ball and Milne as the welcome newcomers and upstarts. This special issue is one such opportunity, providing an outlet for these scholars to disseminate their work more widely. The papers provide an insight in the array of different perspectives and issues canvassed by SEA research that are of concern to not only the newcomers and upstarts but the broader accounting research community.

\footnotetext{
${ }^{1}$ Milne and Ball suggested the current SEA academics could be classified into three succinct groups, namely, 'grandfathers', 'established and privileged', and 'welcome newcomers and upstarts'.
} 


\section{THE SYDNEY 2007 CONFERENCE}

This special issue reflects the work of scholars presented at the $6^{\text {th }}$ Australasian Conference of the Centre for Social and Environmental Accounting Research which was held at the University of Sydney in December 2007. In line with CSEAR's contribution to the development of the paradigm, the Sydney Conference for the first time included a Business and Professional Ethics stream, which created an opportunity for researchers whose interests coalesce with those of CSEAR members to present their research. Given the objective of CSEAR conferences, the number of delegates was restricted to some 70 researchers, mainly from the Asia-Pacific region. In total, 36 papers were presented at the conference and this special issue is a reflection of both the quality and the diversity of this work (for further information and details, please refer to the conference website: http://csear.econ.usyd.edu.au).

\section{THE SPECIAL ISSUE}

This special issue contains five contributions. Mathews (2008) starts the issue off with a review of the celebration of his own work, A Festschrift in honour of M.R. Mathews, which was launched at the CSEAR conference. He contrasts this work with the recently released edited book by Unerman, Bebbington and O'Dwyer (2007), emphasising the different underlying concepts and stressing the shift towards the notion of 'sustainability' in the latter work. His grandfather status allows him to draw on his extensive knowledge in the area and his comments on the developments and reflections of his colleagues' work will, no doubt, sow the seeds for future research.

Accountability is the central theme of the paper by Rika, Tuiloa, Tuiseke and FinauTavite (2008). The paper examines both accounting and accountability in local government in Fiji. The paper highlights a disconnect between indigenous and Western conceptions of accountability. It also demonstrates the difficulties faced by some indigenous communities who live under parallel governance regimes concurrently. Most interestingly the paper demonstrates how language can frame our understandings of accounting concepts such as accountability.

In a traditional style SEA paper, Murthy and Abeysekera (2008) examine the social and environmental reporting practices of Indian software companies through the lens of legitimacy theory. Their study is conducted against the backdrop of India's economic transformation since independence. They focus on corporate social reporting (CSR) of Indian software firms relating to the complex issues of human resources and community development and find support for legitimisation motives for CSR by Indian software firms.

Moore (2008) analyses the impact of public sector reforms on environmental accounting procedures in his case study of a Victorian water utility. The study examines the different reforms in the 1980s and 1990s that influenced the accounting for environmental expenditure in the public sector. The in-depth investigation of how a Victorian water utility dealt and implemented these changes in 2001 follows a framework suggested by English and Guthrie (2001). The findings indicate that little benefit was seen from environmental accounting procedures in the company with efficiency being identified as the main driver for accounting.

The final contribution to this issue reflects the inclusion of the business and professional ethics stream at the conference with the paper by Clarke, Flanagan and O'Neill (2008). This paper questions the position of accounting in the provision of financial information and offers a suggestion to develop a more holistic, interdisciplinary approach to knowledge management in which accountants can play a crucial role as professional financial information providers. 
This suggestion is offered in light of the presentation of a substantial weight of evidence as to the diminishing role of accountants in the provision of financial information.

\author{
Cornelia Beck and Sandra van der Laan \\ Guest Editors \\ February, 2008.
}

\title{
REFERENCES
}

Ball, A. \& Milne, M. (2007). 'Plenary Presentation', $6^{\text {th }}$ Australasian Conference, Centre for Social and Environmental Accounting Research, Sydney, December 2 -4. Available at: http://csear.econ.usyd.edu.au .

Clarke, K., Flanagan, J. \& O’Neill, S. (2008). 'In the Market for Financial Information will the Accountant's 'Expert' Knowledge become Obsolete?', Australian Accounting Business and Finance Journal, Vol. 2 No. 1, pp. 95-107 . https://doi.org/10.14453/aabfj.v2i1.6

English, L., \& Guthrie, J. (2001). Public Sector Management in the State of Victoria 1992-1999: Genesis of the Transformation. In: L. R. Jones, J. Guthrie and P. Steane (eds) (2001), Learning From International Public Management Reform. New York: Elsevier Science Inc. pp. 45-60. https://doi.org/10.1016/S0732-1317(01)11042-0

Gray, R. (2006a) 'Editorial \& CSEAR News', Social and Environmental Accounting Journal, Vol. 26, No. 2, pp. 1-2. https://doi.org/10.1080/0969160X.2006.9651757

Gray, R. (2006b). 'DRAFT: Governance \& the Centre for Social and Environmental Accounting Research', Social and Environmental Accounting Journal, Vol. 26, No. 2, pp. 14-18.

Gray, R. (2007). 'Editorial', Social and Environmental Accounting Journal, Vol. 27, No. 2, pp. 1-2.

Mathew, R. (2008). 'Personal Reflections on a Tale of Two Books: Social and Environmental Accounting Research in the Past, Present and Future', Australian Accounting Business and Finance Journal, Vol. 2 No. 1, pp. 4-14.

Moore, D. (2008). 'Transformation of the Australian public sector and environmental accounting practices: The case of water', Australian Accounting Business and Finance Journal, Vol. 2 No. 1, pp. 74-94. https://doi.org/10.14453/aabfj.v2i1.5

Murthy, V. \& Abeysekera, I. (2008). 'Corporate social reporting practices of top Indian Software firms', Australian Accounting Business and Finance Journal, Vol. 2 No. 1, pp. 38-73. https://doi.org/10.14453/aabfj.v2i1.4

Rika, N., Tuiloa, M., Tuiseke, N. \& Finau-Tavite, S. (2008). 'Accounting and Accountability by Provincial Councils in Fiji: The Case of Namosi’, Australian Accounting Business and Finance Journal, Vol. 2 No. 1, pp. 15-37. https://doi.org/10.14453/aabfj.v2i1.3 